\title{
Research In Creating Artworks - Comparison 3 Case Studies of Fine Art Creative Process
}

\author{
Octalyna Puspa Wardany
}

Graduate School of Indonesia Institute of the Arts Yogyakarta

email: opuspad@gmail.com

\begin{abstract}
In fine arts, creating artworks need doing research. The research has many types. Mostly, it is not the scientific research type. But, nowadays, scientific research is commonly implementing in creating artworks too. It is important to know the various researchs in creating artworks, so it could be able to understand how research has the significant role in creating artworks. This study examines the research in creating artworks through comparation of 3 case studies of fine art exhibitions; (1) the creative process of water color painting exhibition Climen by Surya Wirawan in 2012 which the process held for 4 years (2008-2012), (2) the painting exhibition Melupa by Ugo Untoro in 2013 which the process held for 13 years (2000-2013), (3) the art project Tentang Hutan by gerimisUngu Production 2014 which the process held for 4 years (2011-2014). Each of those 3 creative process has different type of research, methods, and period, artworks as the output, experience of the artist whom get involved, and certain location in Indonesia. These 3 case studies describe that the research in creating artworks can be scientific with fully consideration, or semiscientific in consideration, or unscientific between consideration and uncosideration. And, the certain research implemented in creating artworks is related to the artist (individual and cultural), purpose of the artworks and exhibition, and content of the artworks which appointed.
\end{abstract}

Keywords: artworks, art research, creative process

\section{INTRODUCTION}

In fine arts, creating artworks always begin by certain idea which then actualized by various activities and involving other people to become the artworks. In that actualization, there are exploration and experiment in processing the idea, exercise the materials of artworks, execution process, and finally displaying the artworks in exhibition. These things involves the whole intellectuality of artists' mind and feeling. Also, the artists' social environment and culture give the influence and have the mutual contribution for the artists and their artworks.

Then, is there the research in creating artworks? If there is, what kind and type of research? Is there any exact formulation of the research in creating artworks? Through comparing 3 case studies, this study try to find out those questions in order to understand the research, creating artworks, and its' relation so it is possible to open up the other possibilities in advance the knowledge. The data of this research are obtained by implementing the ethnography method. While 
analysis is implemented the artistic research theory and supported with practiceled research theory.

\section{Case 1: Surya Wirawan's Solo Exhibition}

In December 2012, Surya Wirawan, one painter of Indonesia, held a solo exhibition in Yogyakarta which showed comic paintings using water colour on paper. There were 5 strip comics consist of 5-7 pictures, 7 single paintings on paper seized $18 \mathrm{~cm} \times 15 \mathrm{~cm}$, and 2 comics based from Kiswondo's short stories which are one consist of 20 pictures and the other 30 pictures.

Climen, the title of the exhibition, is from abbreviation of Javanese Cilik-cilik yo Men or Little Things are No Matter in English. The relation of the title can be showed directly from the size which not even get $50 \mathrm{~cm} \times 50 \mathrm{~cm}$ for each painting and the media which used paper and water colour. Considering the condition in that year which was still in fine arts booming so the trading of the artworks is very high; in price and quantity; there was a common agreed that only the big paintings and good media of painting (such as canvas, oil and acrylic paint) which can be sold. So, the Climen exhibition was such the speech from Surya Wirawan to criticize the market condition which then directing the artists in creating artworks for selling purposed.

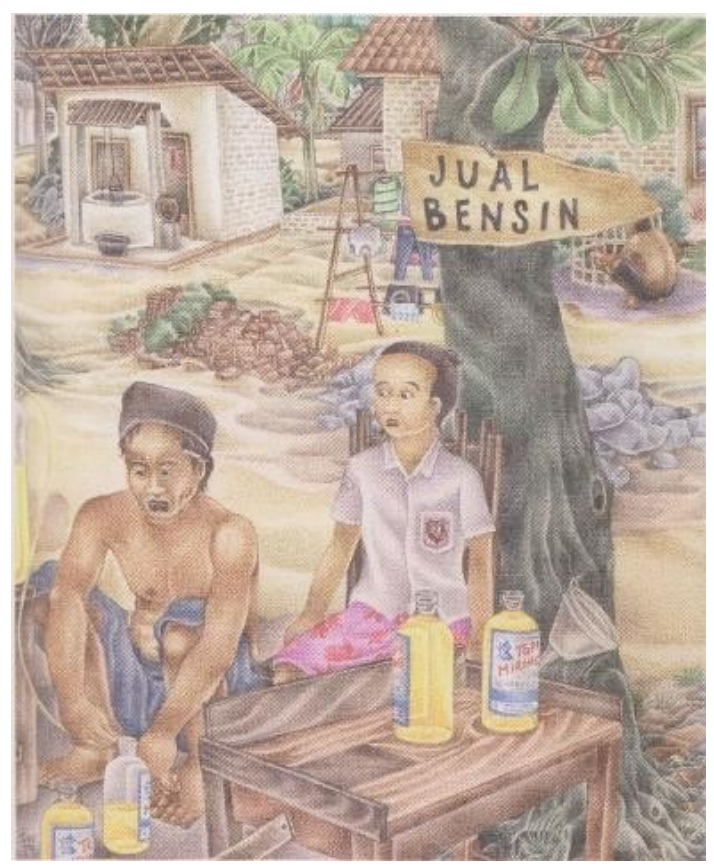

Figure 1: Surya Wirawan

Topi Boleh Miring, Kendil ettap Tegak Water color on paper, $18 \mathrm{~cm}$ x $15 \mathrm{~cm}, 2011$ Source: catalogue of Climen, pp. 39

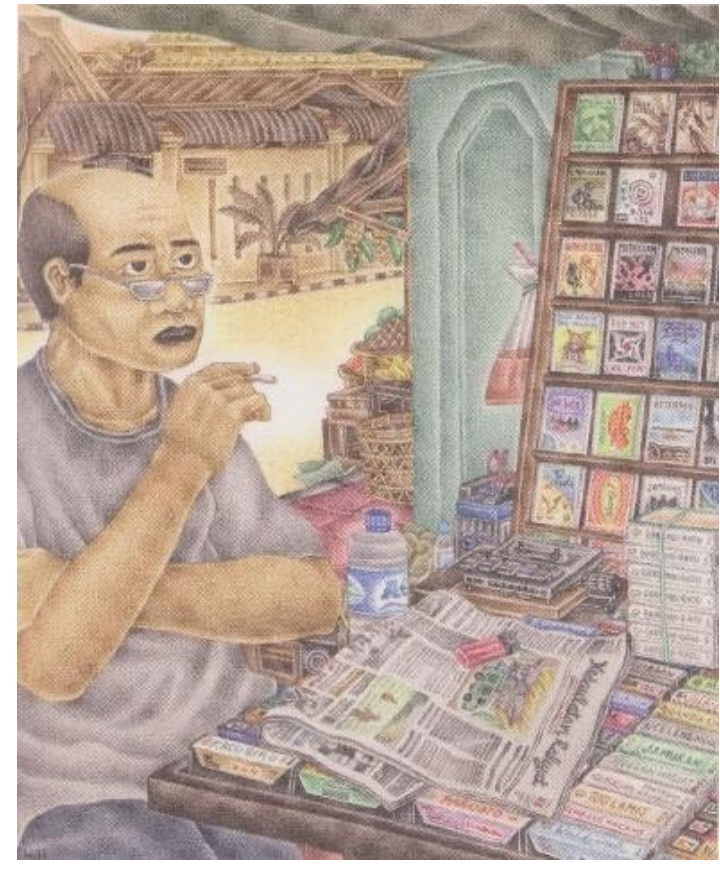

Figure 2: Surya Wirawan

Katanya Hidup Sepi Tanpa Musik Water color on paper, $18 \mathrm{~cm}$ x $15 \mathrm{~cm}, 2011$ Source: catalogue of Climen, pp. 31 
Beside the physical artworks, the contents of all Surya Wirawan's paintings are told about the life of the ordinary people. There are the cassette seller that is not famous anymore in recent digital era, the retail petroleum seller, the seller of lighter gas refill as the content of the single paintings. While in his 4 strip comics, he told about arts activities in booming condition that the artists' main orientation were not communicate and share their ideas by the artworks in exhibition, but selling the artworks. And, in his two comics based on Kiswondo's short stories that ever published in the newspaper, the stories are about the struggle of the family of labour and farmer to solve their live problems related with their fund limitedness. All the artworks which tell about the little things actually happened in our daily lives and slipped away from our concerns.
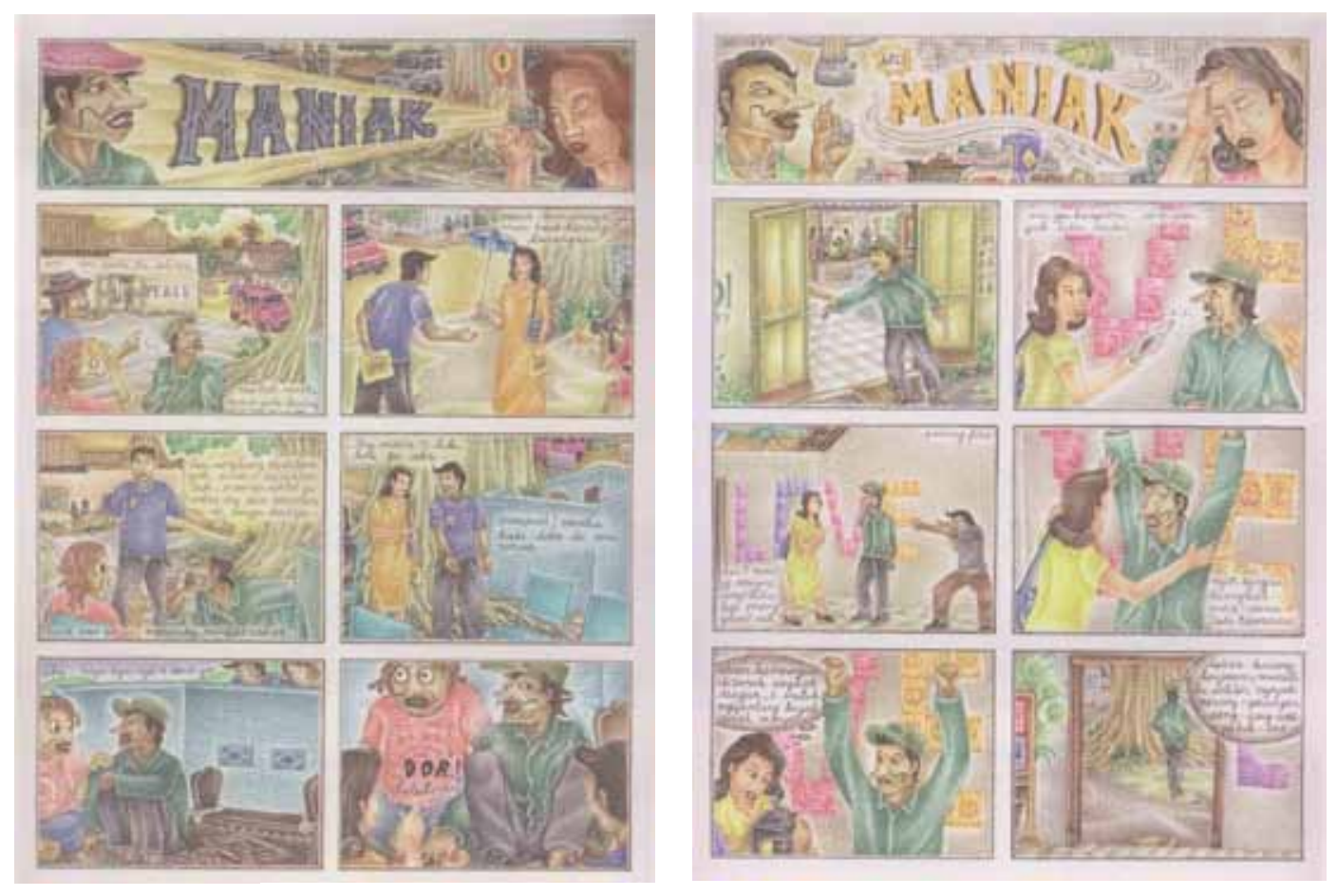

Figure 3: Surya Wirawan

Maniak

Water color on paper, @28 cm x 20 cm (2 pieces), 2011

Source: catalogue of Climen, pp. 34-35

He needed 4 years to prepare all artworks for this solo exhibition. The idea for his 7 single paintings and 5 strip comics came from his daily live that experienced by himself and other people in his social environment. He took the activity that interesting, arranged the object and the speech of each picture, made the sketch on paper and then copy it to transparant paper (see figure 4). Afterward, the sketch on transparant paper is traced to the painting paper, and finally coloured the pictures. For the strip comics, the story was breakdown to some main ideas (see 150 figure 6). Then, composed the main ideas and the pictures including the conversations to the columns of sketch. Especially for 2 comics based on Kiswondo's short stories, he made several meetings with the author to discuss the 
content of the story, the transcription of each story to the comics, the plot story arrangement in the comic which do not exactly the same as Kiswondo's until the comics were realized as the artworks.

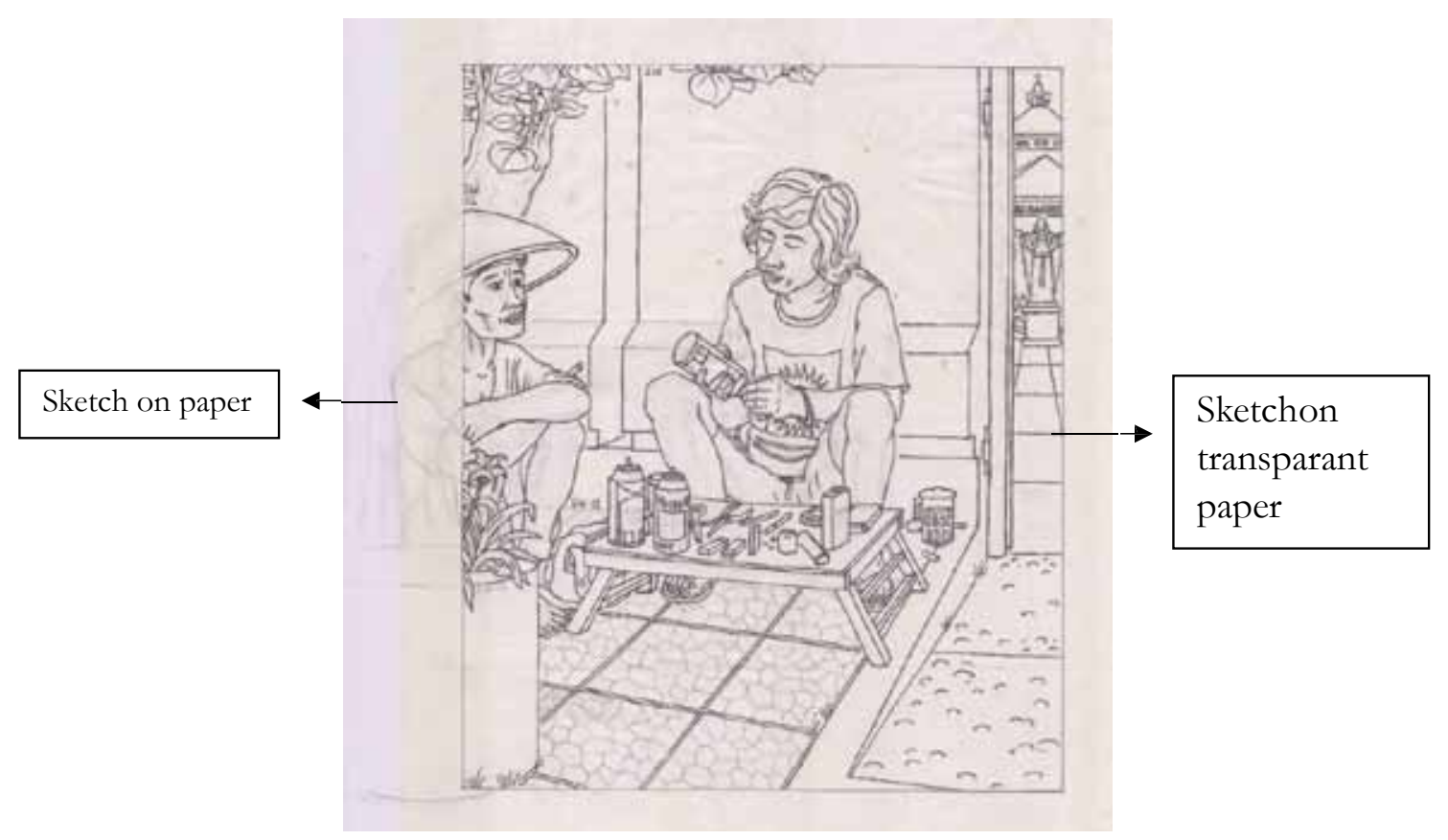

Figure 4: Surya Wirawan

Sketch of Kowe Telungatus Aku Pitung atus

Pencil on paper

Source: Surya Wirawan archives

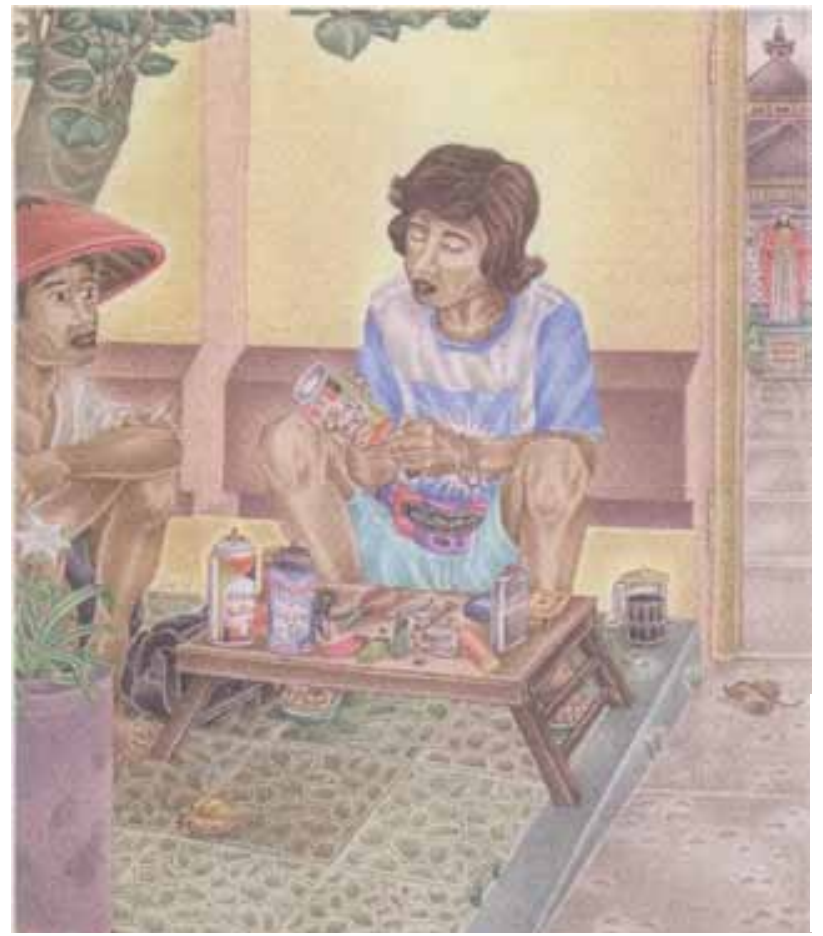

Figure 5 : Surya Wirawan

Kowe Telungatus Aku Pitungatus

Water color on paper, $18 \mathrm{~cm} \times 15 \mathrm{~cm}, 2012$

Source: catalogue of Climen, pp. 32 


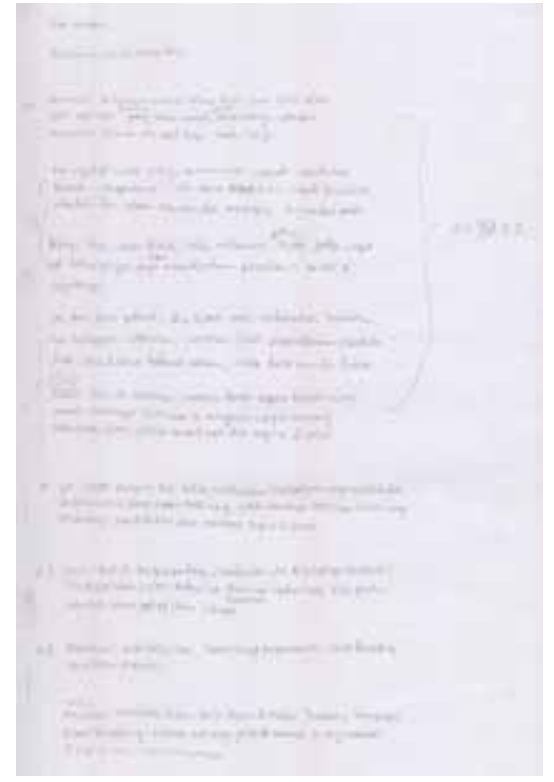

Figure 6: Surya Wirawan

The Design Short Story Breakdown of Kalender Pencil on paper

Source: Surya Wirawan archives

He was exploring special technique in colouring his artworks. He was using two steps painting for each colour. Firstly, he brushed the water colour in certain area. Then, he brushed the water in that area by different paintbrush. He had been explored this technique since 1994 using acrylic and canvas media at that time. He felt that getting successful in implementing this technique by water colour in this exhibition. Though, in his solo exhibition in 2008, he had presented this technique using the same media, but he did not satisfied yet. In Climen, the colour in his artworks are looked very soft and transparent so many people did not believe that those artworks are using water colour. An artist of fine art even presumed that Surya Wirawan was using pencil colour then brushed with water in colouring his artworks.

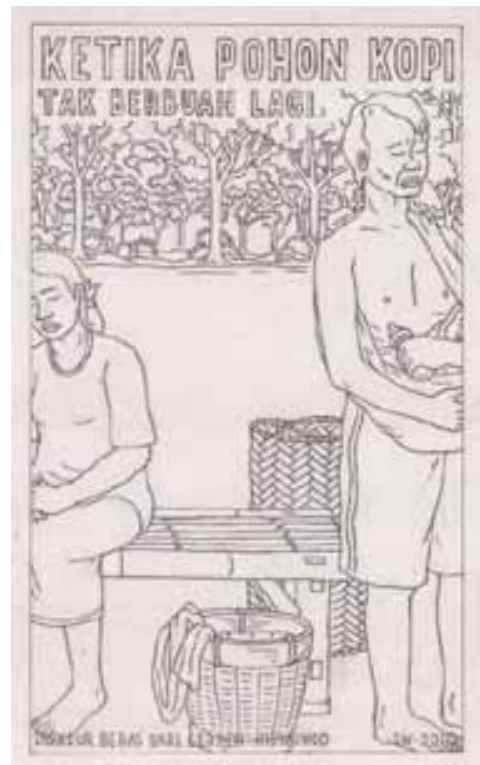

The Sketch

Pencil on paper

Source: Surya Wirawan's archives

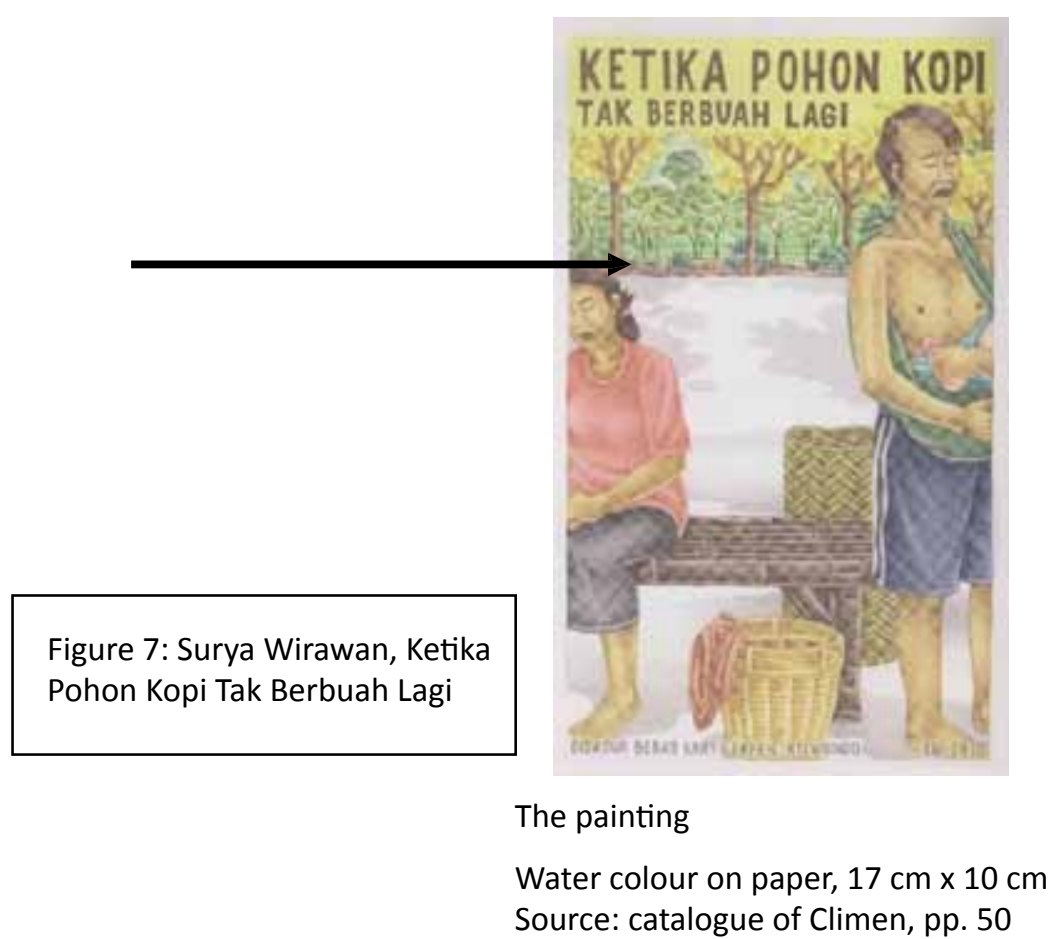


To draw the painting objects as real as it looked, he was doing observation of the real objects. For drawing the coffee leaves of the comic Ketika Pohon Kopi Tak Lagi Berbuah (When Coffee Trees Have No Bear Fruit Anymore) which is not common for him, he observed the coffee tree and its leaves in his neighbour. So, there were the study process in drawing the objects by sketching which was documented neatly.

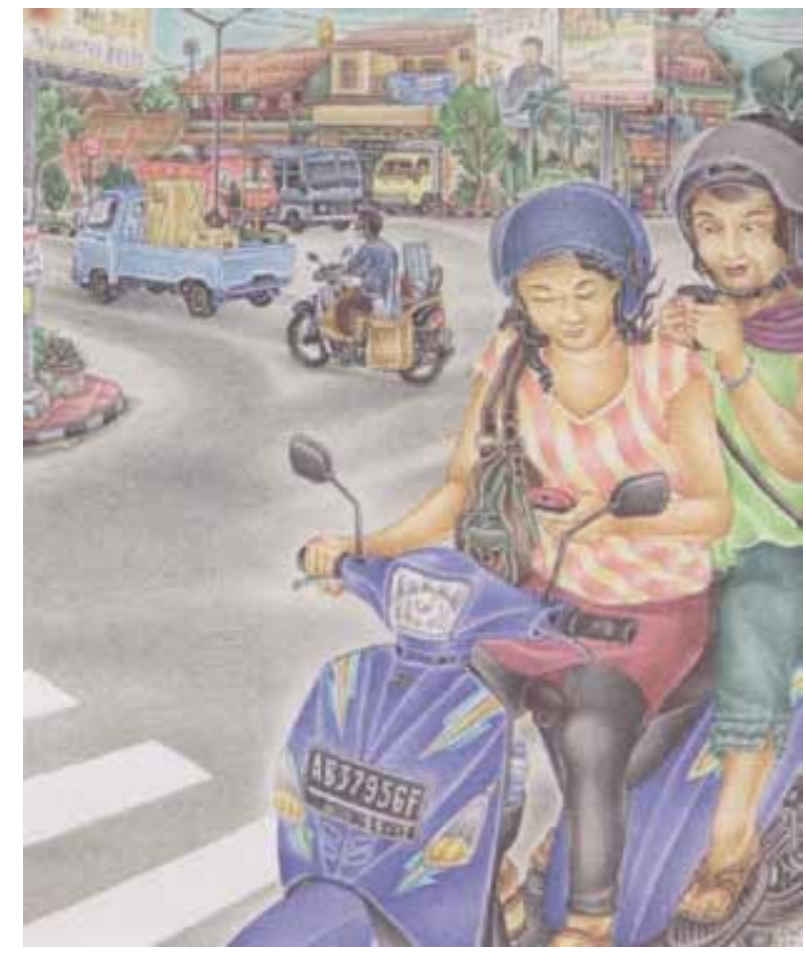

Figure 8: Surya Wirawan, Banyak Jalan Menuju Rumah Sakit Water color on paper, $18 \mathrm{~cm} \times 15 \mathrm{~cm}, 2012$ Source: catalogue of Climen, pp. 28

His paintings which tell about the live of lower class people and daily common activities showed his alignments that is for little people. It is parallel with his way of life that is very modest and ordinary. However, he kept criticizing the habit of common people that danger other people and themselves in driving (see figure 8). Overall, his artworks and choice of his way of life are showed his ideology about social live of common people. His ideology in this exhibition did not appear explicitly as his previous artworks; painting and printmaking in his beginning period as the painter. The implicitly appearance of his ideology that can be detected by content, materials, and objects of his artworks penetrated through his long journey in creating artworks since 1991.

\section{Case 2: Ugo Untoro's Solo Exhibition}

The solo exhibition by Ugo Untoro in 2013 which showed literature painting; poems and fiction short story or unfinished short stories; was needing 13 years intensive process which were shown by Ugo's artworks documentation. He started by painting any words and sentences in 2000. In the beginning of his experiment (2000-2001 and 2004), he combined the literature text, numbers, figures, and object on canvas. After vacuum for 2 years (2002-2003), he was 
doing the experiment by sketches. He studied the placement of the text, the composition, and the shaped that was arranged by the text, the colour, the image area through sketches. This study happened for 2 years (2005-2006).

Afterward, he started the experiment using canvas. In 2007, he explored technique, text size and length, and background colour of the canvas. In 2008, he explored painting short text which are gave certain information. In 2009, he explored focus of interest by painting tiny texts on big canvas. In 2010, he already painted the scribbled text on the canvas freely and combining the different materials as the media (paper and canvas). Since 2011, he created artworks for his solo exhibition titled Melupa which presented all his experimentation and exploration in materials, technique, and aesthetic elements.

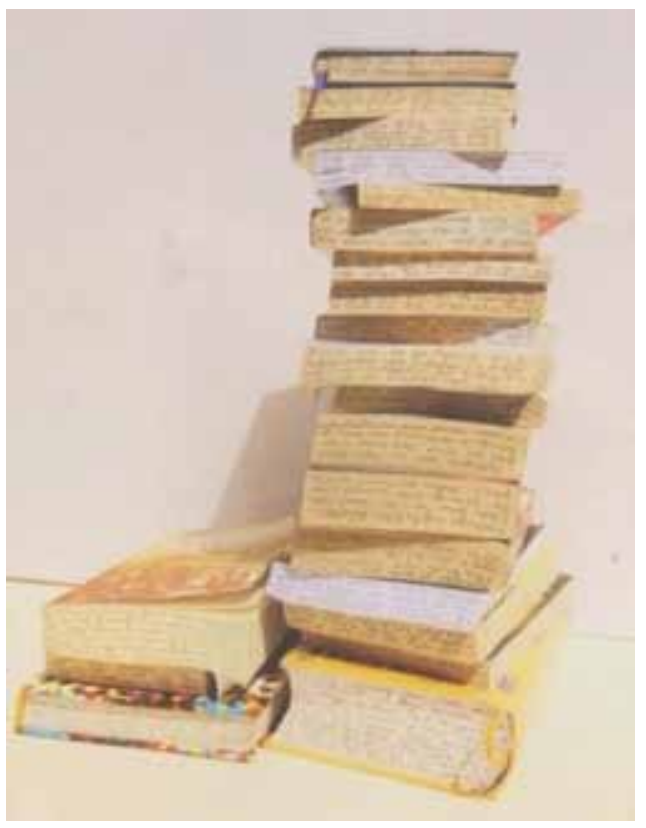

Figure 9: Ugo Untoro,

\section{Object\#1,}

ballpointon book, life-sizebook, 2013

Source: catalogue of Melupa, pg. 4

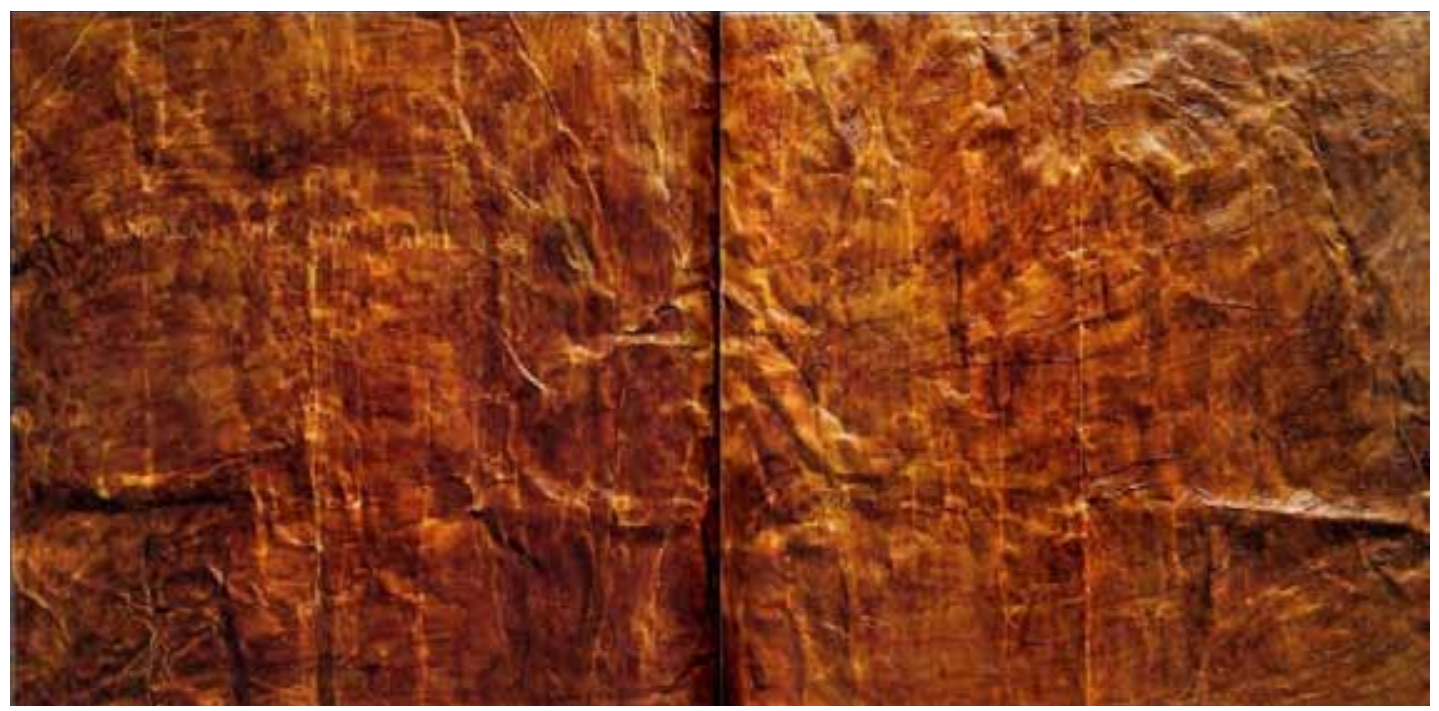

Figure 10: Ugo Untoro, Departure, wax on fabric, $105 \mathrm{~cm}$ x 250 m, 2013

Source: catalogue of Melupa, pg. 30-31 


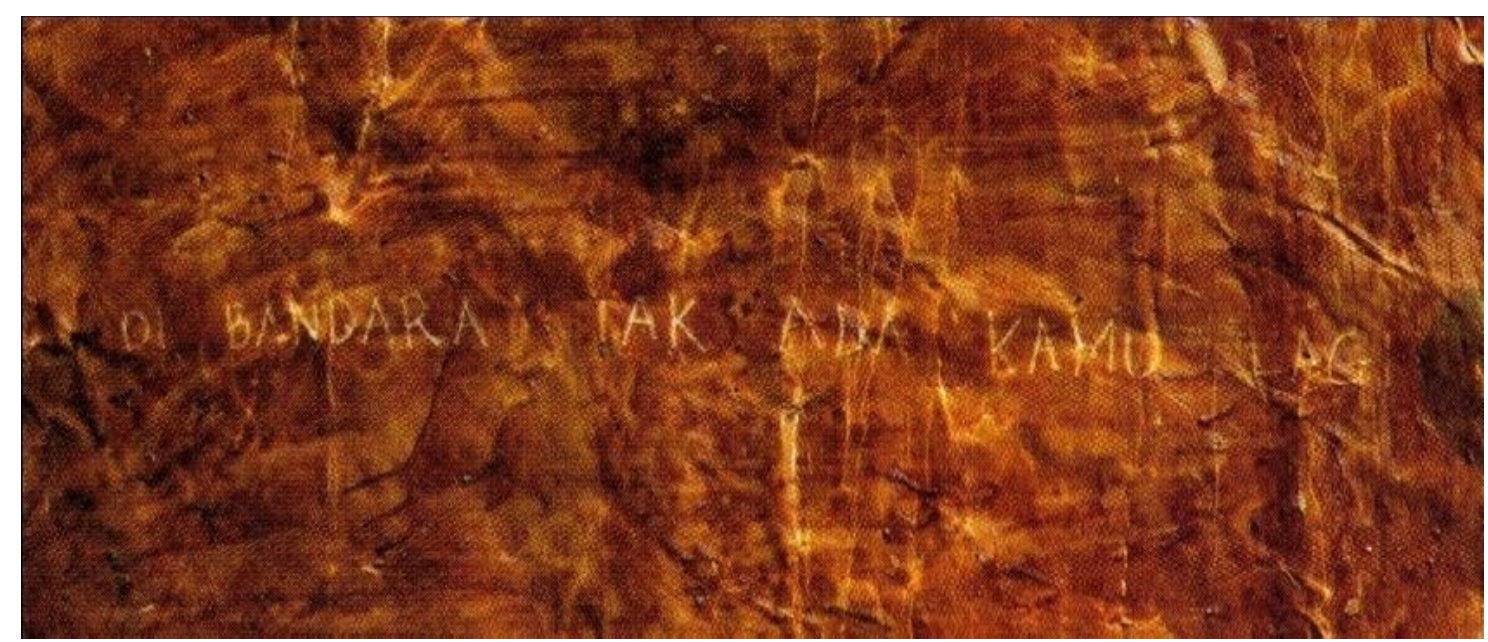

Figure 11: Ugo Untoro, Departure (detail), wax on fabric, $105 \mathrm{~cm}$ x $250 \mathrm{~cm}, 2013$ Source: catalogue of Melupa, pg. 30-31

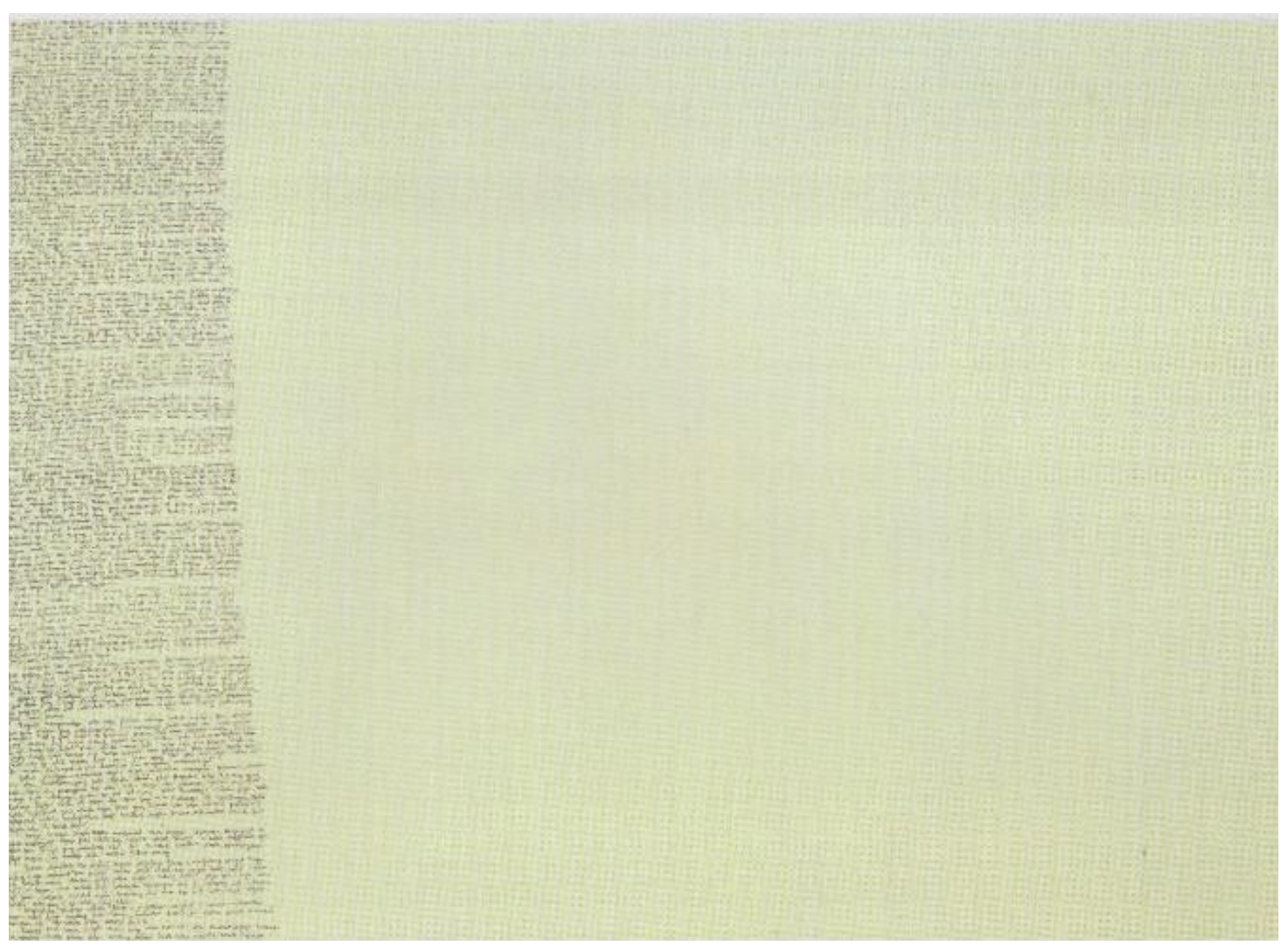

Figure 12: Ugo Untoro, Regasa, markeron canvas, $250 \mathrm{~cm}$ x $180 \mathrm{~cm}, 2013$ Source: catalogue of Melupa, pg. 21

Poems and fiction as the format of the texts in his paintings are influenced by the books he read since he was a child which literature has a big portion of his interest beside the book of fine arts and comic. Comic then became one of his narrative styles in his text paintings. While the content of his paintings tell about social relationship of the human being in build up the live. His text paintings mention about power, chance, potentiality, the harmony with nature, beliefs, economic 
benefits, dreams, love to explain his concerns. All the content materials are cached from his personal experiences, the live in his neighbourhood, and combining with his imagination and fantasy which get from his adventure in various fictions. Thus, there is the literature study in creating his artworks. Though he doesn't intend the specific literature study to create certain artwork (painting and exhibition) and reading become as his habit, he has the consideration to involve what he has gotten from the literature to create his artworks.

The study in this exhibition is also implemented in creating his literature paintings. In 2007, he ever watched the text painting exhibition in Art Bassel 2007 of Venice. As mentioned previously, in 2007 he started to do the exploration in painting the text intensively. The Art Bassel text exhibition then influenced he to be freer and courage in realised his idea. It gave him the spirit to execute his idea about literature paintings. So, the reference of other similar type artworks became very important in creating artworks as a sign that his idea is make sense and find out the different type of text paintings which had not existed yet that is literature.

\section{Case 3: Art Project of Collective artists}

The art project which titled Tentang Hutan (About Forest) involved a researcher in anthropology field and 8 artists of fine arts. The artistic work stages in this art project are composed clearly. It started with a research about The Impact of Social Movement on The Socioeconomic Security of the Peasants in Ngadisono Village, Wonosobo of Central Java in 2011-2012 by Dwi Any Marsiyanti. The research result explains about the benefit that community surrounding industrial forest is gotten by the implementation of joint forest management between the company and community. Based on this result, the emerging artists were recruited by considering their field of works in fine arts and their competency. Then, the team consists of 8 artists recruited, researcher and curator discussed about the research results and the implementation of this art project.

Thereafter, the absorb phase started. The artists and curator lived in the location for a month. While they were staying, they search tangible and intangible information and data by beginning with the meeting with representatives of community, interview related parts, informal conversation with the community who came to the basecamp, got involved in the community activities, go to the industrial and community forests, go to the historical sites and public spaces in the village. During searching the information, the team held the regular meeting to share and discuss their findings and opinions. All information and data in the absorb phase then shared to the public in a discussion. In this discussion, the team also got many inputs that is very useful as the sharpening in the artworks and the art project itself.

Then, the artists were creating artworks for 4 months. During creating artworks, it was possible to get back to the location if necessary and also meet the researcher to get more information. In this phase, the intensive discussion between the artists and curator is important so artists' needs can be detected and facilitated rapidly. 
After the artworks done, all were presented to the community in the art project location. Though the local community are common with traditional arts, they were able to enjoy the contemporary artworks. This presentation became the forum for artists and local community to have the conversation about the artworks, the certain location in their village which showed in the artworks.

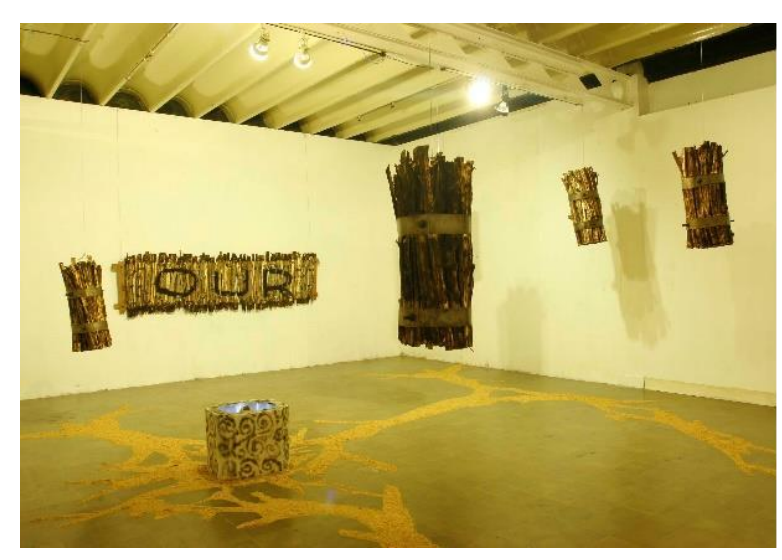

Figure 13: Bukit Bentang (Bentang Hill) Instalation of Dwi Joko Harianto Source: gerimisUngu archives

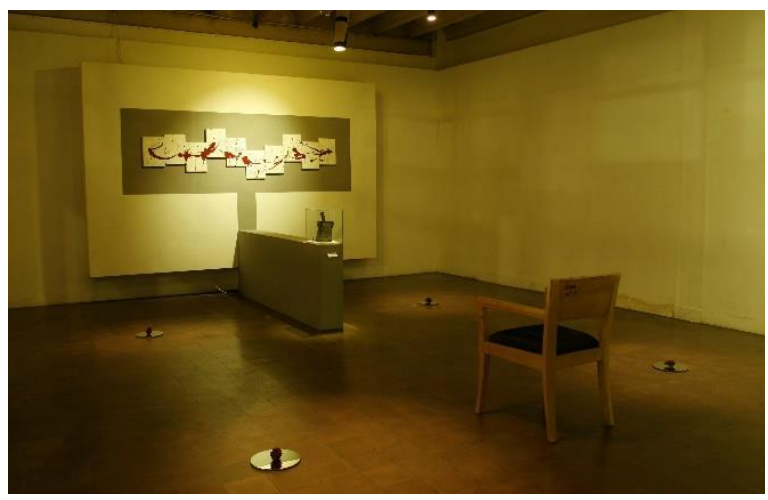

Figure 14: Jalan Panjang (The Long Way) Instalation of Allatief Source: gerimisUngu archives

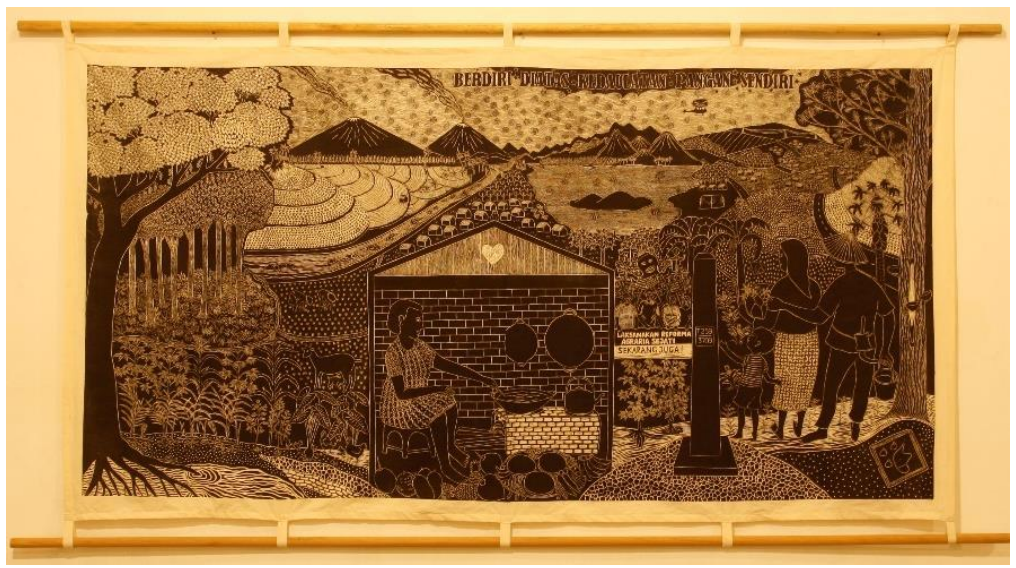

Figure 15: Berdiri di Atas Kedaulatan Pangan Sendiri (Stand on Its Food Sovereignty) Printmaking artwork of Fitri DK Source: gerimisUngu archives

Finally, all the artworks were presented in the exhibition. There are 17 artworks in various media; painting, photo of performance art, video art, installations, printmaking artworks, photography, videography, music performance, Japanese calligraphy, printmaking; and research result display during a week. Those artworks have different content in expressing about forest, such as: the bound between the community and the forest (figure 13), the long struggle by the community in getting the authorization to have the joint management in the 
land of industrial forest (figure 14), the landscape of village which most area is forest (figure 15), the daily work of the farmers related to forest (figure 16), the contradictive of citizen forest and industrial forest related to natural destroy (figure 18), the spirit that arising when stay in the forest (figure 17). This exhibition was ended with the public discussion to share about the research, the art project, the real story which involved also a representative of local community as the resource person. To close the whole art project, there was an evaluation meeting to review all the phases, method, artworks, and management.

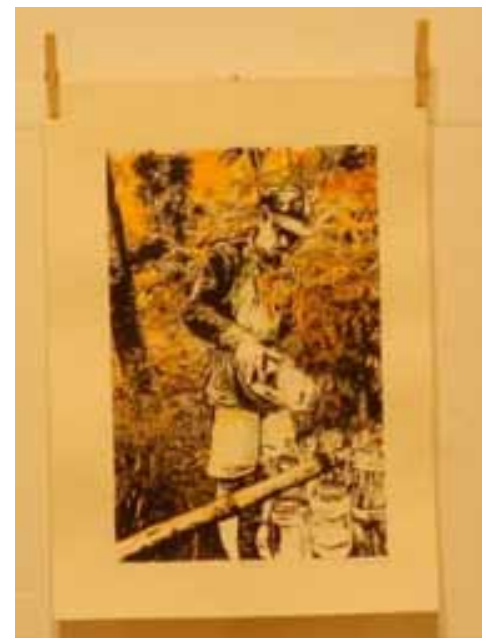

Figure 16: Penderes (Bentang Hill) Screen printing of Isrol Media legal Source: gerimis Ungu archives

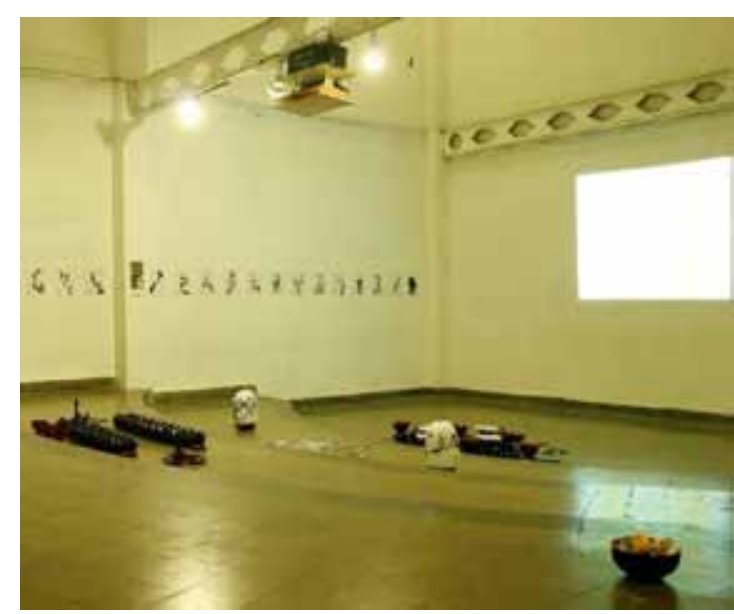

Figure 17: Rear Shin Ku Instalation of Hiroshi Mehata Source: gerimis Ungu archives

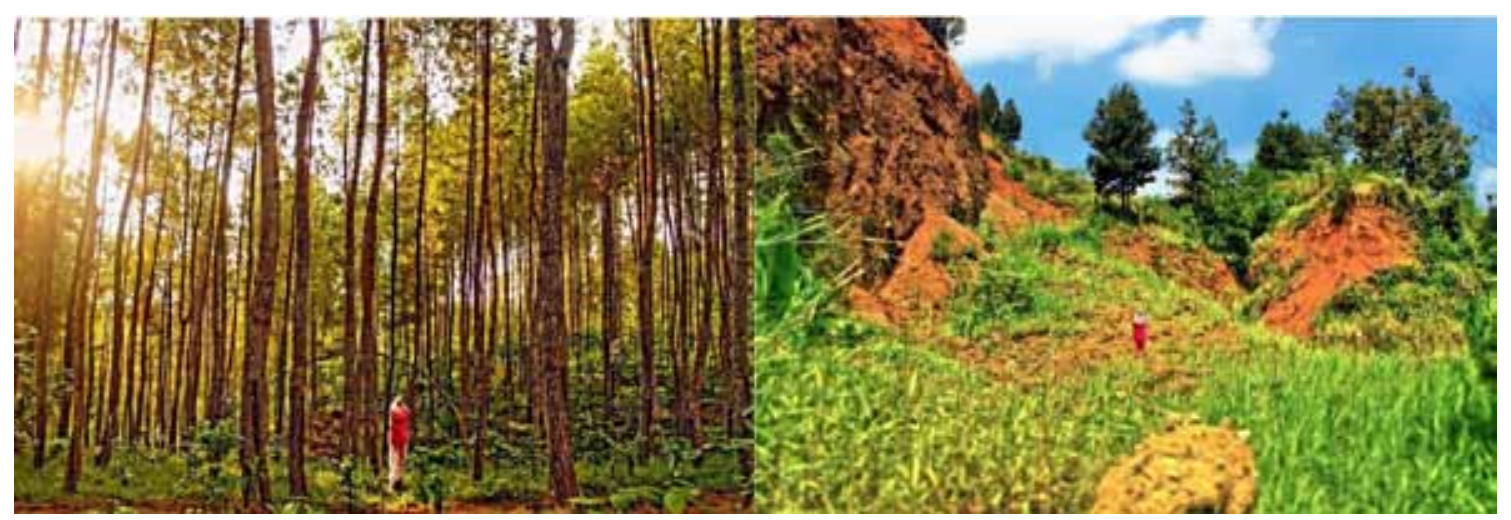

Figure 18: Melanomata

Photo Performance Art of Ferial Afiff

Source: gerimis Ungu archives

This art project enable the interaction between the artists and community in certain issue which not event learned by the artists previously. The artworks present the real live and problem of certain community by explore the artists' knowledge, evidences, and aesthetic understanding. The scientific research which held using ethnography method gives the valid data that helps the artist to catch the problems and enable them to concentrate doing their research for creating artworks. The art project as one model of artistic research then makes 
creating artworks based on the real issue and problems in community is occurred effectively which in this case is 8 months. However, this art project hasn't completed yet. The implementation of the phases should be improved which will be experimented in the next art project.

\section{RESEARCH IN CREATING ARTS}

Are those 3 cases of creating artworks able to be mentioned as research? To classify those creating arts processes as research, it should be identified the research elements which exist in those 3 cases. Refer to Graeme Sullivan (1988:

46):

"Research is a reified entity within university life and the common perception is to maintain codified practices that determine not only what is endorsed as legitimate inquiry but also the conditions under which research is conducted and sanctioned".

Research then cannot only considered by the implementation of method, tool, and theory to analyse the data in order to get the certain results as the answer of the research questions and reach the research goals so it is beneficial. Research is involving the life as the resource data or resource idea which has particular problems as the trigger for the researcher. Life is then the daily existence that is experienced by the researchers directly and indirectly. In creating arts, the element of life exist. As describe in the 3 cases above, the artists do creating process by catch and explore their life including habits, activities, and involvement. Though, the art process was done by collective artists in relatively short period, there are the phase when they not only catch the life data through written research results and other written information. They were still necessary to get involved in the real life of the resources. Then, Sullivan complete definition of research by the need of common perception as codified practices. This second element become the guide to examine whether research implements in creating artwork or not.

As Mika Hannula, Julian Suoranta, and Tere Vadén (2005: 20) mention, "research of scientific has two means; scientific argumentation and artistic criteria". However, as mentioned next, (2005: 17) "science is not one well-defined entity, but rather that there are many sciences and that the sciences can sometimes have different and possibly even incommensurable goals". In this point, there is the possibility to define that creating artworks have research process and those 3 authors postulate the term of artistic research (2005: 19) which is still in continuous search and convincing definition. As the consequent (2005: 21), "artistic research has a loosely connected set of goals or purposes, through which its relevance becomes evident". Thus, to consider whether research is exist in creating art or not, it could be examined by reviewing its relevance.

The 3 authors then explain about the relevance of artistic research -which is by its nature is relative, uncertain and changing, but at the same time experimental, an intellectual pleasure creating new knowledge- are (1) specifies the localization and specific locality of the work, taking it forward, increasing its profundity, and 
(2) contents and its production, participation in the process of forming meanings as the central points -rather than form or formalities (see 2005: 152-153).

The specifies localization refer to the localization of certain understanding, while specific locality of the work means the certain place as the resource idea, or the place to execute idea to be artworks, or the place to presenting the artworks and sometime not even related to certain point of place. It is about the localization of certain understanding. For example, the localization specifies of Surya Wirawan's artworks is the domain of common people (lower class people) and the specific locality of the work is in Indonesia. While the specifies localization of Ugo Untoro's artworks is universal as its specific locality of the work, but the language of the text make Ugo Untoro's artworks are relevant for Indonesia. In the art project, though its specific locality of the work is at the village level (Ngadisono), its' specifies localization could be in effect global where forest as its concern. Each 3 cases have different motion plot of specifies localization and specific locality which presented by the objects, the content, the media, and symbols used of their each artworks.

The second element of the relevance of artistic research relies on paradigm of the researcher and the research design. As mentioned, it is possible to analysis the form or formalities to understand the meaning of artworks. But, if the researcher would like to make the artistic research, the analysis uses those 3 things mentioned. The researcher does not always other person/s who study the creating artworks process. It can be the artist/s who creating the artworks when presenting not merely the output, also those 3 things in the second element.

\section{CONCLUSION}

The process creating artworks from composing idea until presenting the artworks is actually the research works. It can be classified as the artistic research. By study the 3 case of creating artworks, the format of artistic research is diverse. So, the chance to bring forward different format is very wide-open which is able to develop and enrich the knowledge of artistic research then benefit the advancement of art.

\section{REFERENCES}

Csikszentmihalyi, M. (1999). Implications of a Systems Perspective for the Study of Creativity.

In R. J. Sternberg (Eds.), Handbook of Creativity (pp. 313-335). United Kingdom: Cambridge University Press.

Hannula, M., Suoranta, J. \& Vadén, T. (2005). Artistic Research-Theories, Methods and Practice. Helsinki: Academy of Fine Arts.

Marsiyanti, D. A. (2012). Social Movement di Ngadisono (Paper). (2012). Dampak Gerakan Sosial pada Keamanan Sosial-Ekonomi bagi Petani Penggarap di Indonesia (Research Result)

Sachari, A. (2005). Pengantar Metodologi Penelitian Budaya Rupa (pp. 147-153). Bandung: Erlangga.

Saukko, P. (2003). Doing Research in Cultural Studies. Gateshead: Athenaeum Press. 
Sullivan, G. (2009). Making Space: The Purpose and Place of Practice-led Research in H. Smith \& R. T. Dean (Eds.), Practice-led Research, Research-led Practice in the Creative Arts (pp. 41-51, 62). Edinburgh: Edinburgh University Press.

Svašek, M. (2007). Anthropology, Art and Cultural Production (pp. 154-155 \& 187190). London: Pluto Press.

Wardany, O. P. (2016). Proses Kreatif Penciptaan Seni Lukis, Studi Kasus Pameran Pameran Tunggal Ugo Untoro "Melupa" (Master Thesis). Retrieved from ISI Yogyakarta.

Gerimisungu (2014). Art Project: Tentang Hutan (Exhibition Catalogue). Yogyakarta: Gerimisungu Production.

Untoro, Ugo (2013). Melupa (Exhibition Catalogue). Yogyakarta: Ark Galerie.

Wirawan, S. (2012). Climen (Exhibition Catalogue). Yogyakarta: Jogja Contemporary.

Surya Wirawan (personal interview, August 6, 2016). 